\title{
Correspondence between gene expression and neurotransmitter receptor and transporter density in the human brain
}

\author{
Justine Y. Hansen ${ }^{1}$, Ross D. Markello ${ }^{1}$, Lauri Tuominen ${ }^{2}$, Martin Nørgaard ${ }^{3}$, \\ Elena Kuzmin ${ }^{4}$, Nicola Palomero-Gallagher ${ }^{5}$, Alain Dagher ${ }^{1}$, Bratislav Misic ${ }^{1 *}$ \\ ${ }^{1}$ McConnell Brain Imaging Centre, Montréal Neurological Institute, McGill University, Montréal, Canada \\ ${ }^{2}$ Department of Psychiatry, The Royal's Institute of Mental Health Research, University of Ottawa, ON, Canada \\ ${ }^{3}$ Neurobiology Research Unit \& CIMBI, Copenhagen University Hospital, \\ Copenhagen, Denmark; Center for Reproducible Neuroscience, \\ Department of Psychology, Stanford University, Stanford, California, USA \\ ${ }^{4}$ Department of Biology, Centre for Applied Synthetic Biology, \\ Concordia University, Montréal, Canada; Department of Human Genetics, \\ Rosalind \& Morris Goodman Cancer Institute, McGill University, Montréal, Canada \\ ${ }^{5}$ Institute of Neuroscience and Medicine (INM-1), Research Centre Jülich, \\ Germany; Department of Psychiatry, Psychotherapy and Psychosomatics, \\ Medical Faculty, RWTH, Aachen, Germany; C. and O. Vogt Institute for Brain Research, \\ Heinrich Heine University Düsseldorf, Düsseldorf, Germany.
}

\begin{abstract}
Neurotransmitter receptors modulate the signaling between neurons. Thus, neurotransmitter receptors and transporters play a key role in shaping brain function. Due to the lack of comprehensive neurotransmitter receptor/transporter density datasets, microarray gene expression is often used as a proxy for receptor densities. In the present report, we comprehensively test the expression-density association for a total of 27 neurotransmitter receptors, receptor binding-sites, and transporters across 9 different neurotransmitter systems, using both PET and autoradiography imaging modalities. We find poor spatial correspondences between gene expression and density for all neurotransmitter receptors and transporters except four single-protein metabotropic receptors (5- $\mathrm{HT}_{1 \mathrm{~A}}, \mathrm{D}_{2}, \mathrm{CB}_{1}$, and MOR). These expression-density associations are related to population variance and change across different classes of laminar differentiation. Altogether, we recommend using direct measures of receptor and transporter density when relating neurotransmitter systems to brain structure and function.
\end{abstract}

\section{INTRODUCTION}

Neurotransmitter receptors and transporters support synaptic communication, regulating signal transmission from neuron to neuron. As such, regional variation of receptor and transporter distributions shapes the functional specialization of the brain $[27,34,60,79,84$, 91]. Recent studies have used receptor densities to tune computational models and have related specific receptors, as well as excitatory-inhibitory ratios, to neurodevelopment, cognition, neural dynamics, and disease $[20,39,44,64,80]$. However, due to the lack of comprehensive neurotransmitter receptor and transporter density datasets (open-source or otherwise), receptor/transporter densities are often substituted with microarray gene expression from the Allen Human Brain Atlas [37], under the assumption that levels of gene expression are correlated with cell surface protein abundance $[6,14-16,20,30,33,39,44,64,65,80]$.

Despite the frequent replacement of receptor/transporter densities with gene expression, the assumed correlation between gene expression and receptor/transporter density has yet to be comprehensively and formally tested across multiple neurotransmitter systems. Indeed, there are several reasons gene expression may not be correlated with receptor density. First,

\footnotetext{
*bratislav.misic@mcgill.ca
}

microarray gene expression measures the outcome of gene transcription and the abundance of mRNA, not levels of protein. Importantly, levels of mRNA and protein are often not correlated within the same tissue $[52,76]$. Second, several steps are involved between protein translation and expression of the receptor/transporter on the cell surface, including post-translational modifications, protein folding, and reaching a designated cellular target. Variations in the activity of these processes will affect receptor/transporter density. Third, multiple genes in the Allen Human Brain Atlas show high intersubject variability, indicating the possible unreliability of such group-averaged expression levels. Altogether, a comprehensive study mapping receptor/transporter densities and gene expression levels is necessary to determine whether neurotransmitter receptors and transporters show density-expression associations in the human cortex.

Here we investigate whether microarray gene expression can be used to estimate neurotransmitter receptor/transporter densities in the cortex. To measure gene expression levels, we use the Allen Human Brain Atlas that code for specific neurotransmitter receptors or transporters [37, 47]. Additionally, we use both positron emission tomography (PET)- and autoradiography-derived measures of neurotransmitter receptor densities for a total of 27 neurotransmitter receptors and transporters across 9 different neurotransmitter systems $[1,8,10,22-24,31,38,41,42,56,58$, 
$59,62,71,74,82,91]$. To ensure results are not biased by methodological choices, we repeat our analyses in a separate parcellation resolution and use a conservative spatial autocorrelation-preserving null model [2, 49]. We find that measures of gene expression can generally not be used as a proxy for receptor nor transporter density except for a select few neurotransmitter receptors: $5-\mathrm{HT}_{1 \mathrm{~A}}$ (serotonin), $\mathrm{D}_{2}$ (dopamine), $\mathrm{CB}_{1}$ (cannabinoid), and MOR (opioid). Finally, we provide evidence that the link between receptor/transporter density and gene expression is related to inter-subject genetic variability.

\section{METHODS}

All code and data used to perform the analyses can be found at https://github.com/netneurolab/hansen gene-receptor.

\section{PET data acquisition}

Volumetric PET images were collected for 18 different neurotransmitter receptors and transporters across 9 different neurotransmitter systems $[1,8,10,22-$ $24,31,38,41,42,56,58,59,62,71,74,82,91]$. To protect patient confidentiality, individual participant maps were averaged within studies before being shared. Each study, the associated receptor/transporter, tracer, number of healthy participants, age, and reference with full methodological details can be found in Table S1. In all cases, only scans from healthy participants were included. Images were acquired using best practice imaging protocols recommended for each radioligand. Altogether, the images are an estimate of receptor densities and we therefore refer to the measured value (i.e. binding potential, tracer distribution volume) simply as density. PET images were all registered to the MNI-ICBM 152 nonlinear 2009 (version c, asymmetric) template, then parcellated to a parcellation with 68 and 219 cortical regions, as well as 15 subcortical regions, according to the Lausanne atlas $[17,21]$. Receptors and transporters with more than one mean image of the same tracer (i.e. 5$\mathrm{HT}_{1 \mathrm{~B}}, \mathrm{D}_{2}, \mathrm{mGluR}_{5}$, and VAChT) were combined using a weighted average. Finally, each tracer map corresponding to each receptor/transporter was z-scored across regions and concatenated into a final region $\times$ receptor matrix of relative densities. This data was presented and used originally in [35].

\section{Autoradiography data acquisition}

In vitro receptor autoradiography data were originally collected and processed as described in [91]. Fifteen neurotransmitter receptor densities across 44 cytoarchitectonically identified areas in three post-mortem brains were acquired from Supplementary Table 2 of [91] (see
Table S2 for a complete list of receptors included in the autoradiography dataset). Note that $G_{A B A}$ and $\mathrm{GABA}_{\mathrm{A} / \mathrm{BZ}}$ refer to the same receptor, but that $\mathrm{GABA}_{\mathrm{A} / \mathrm{BZ}}$ refers specifically to $\mathrm{GABA}_{\mathrm{A}}$ receptors containing the allosteric benzodiazepine binding site, as opposed to receptors containing only the GABA neurotransmitter binding site. To best compare PET data analyses with the autoradiography dataset, a region-to-region mapping was manually created between the 44 available cortical regions in the autoradiography dataset and the $34 \mathrm{left}$ hemisphere cortical Desikan Killiany regions. In only one case (the insula) was there no suitable mapping between the autoradiography data and the Desikan Killiany atlas. As such, the 44-region autoradiography atlas was converted to 33 Desikan Killiany left hemisphere regions. Finally, receptor densities were z-scored and averaged across laminar layers, to create a single map of receptor densities across the cortex.

\section{Microarray gene expression}

Regional microarray expression data were obtained from six post-mortem brains provided by the Allen $\mathrm{Hu}-$ man Brain Atlas (http://human.brain-map.org/) [37]. Since only two of the six brains included samples from the right hemisphere, main analyses were conducted on the left hemisphere only. All processing was performed using the abagen toolbox (https://github.com/ netneurolab/abagen [47]). These data were processed and mapped to parcellated brain regions at 34 and 111 left hemisphere cortical grey matter nodes according to the Lausanne anatomical atlas $[17,21]$. For completeness, data were also parcellated to 15 bilateral subcortical regions. Due to the coarse subcortical parcellation, sufficient probes were available for both hemispheres. We therefore show expression-density associations across 15 bilateral subcortical regions in Fig. S1 but due to the low number of observations (brain regions), we do not report nor interpret corrrelation coefficients or $p$-values.

Microarray probes were reannotated using data provided by Arnatkevičiūte et al. [3]. A single microarray probe with the highest differential stability, $\Delta_{S}(p)$, was selected to represent each gene [36], where differential stability was calculated as:

$$
\Delta_{S}(p)=\frac{1}{\left(\begin{array}{c}
N \\
2
\end{array}\right)} \sum_{i=1}^{N-1} \sum_{j=i+1}^{N} r\left[B_{i}(p), B_{j}(p)\right]
$$

Here, $r$ is Spearman's rank correlation of the expression of a single probe $p$ across regions in two donor brains, $B_{i}$ and $B_{j}$, and $N$ is the total number of donor brains. Differential stability is the average correlation across every pair of donor brains of a probe's expression. This procedure retained 20232 probes, each representing a unique gene. 
Next, samples were assigned to brain regions using MNI coordinates generated via non-linear registrations (https://github.com/chrisfilo/alleninf) by finding the nearest region, up to $2 \mathrm{~mm}$ away. To reduce the potential for misassignment, sample-to-region matching was constrained by hemisphere and cortical/subcortical divisions [3]. If a brain region was not assigned any sample based on the above procedure, the sample closest to the centroid of that region was selected in order to ensure that all brain regions were assigned a value.

Inter-subject variation was addressed by normalizing tissue sample expression values for each donor across genes using a scaled robust sigmoid function [29]:

$$
x_{n o r m}=\frac{1}{1+\exp \left(-\frac{\left(x_{g}-\left\langle x_{g}\right\rangle\right)}{\mathrm{IQR}_{x}}\right)}
$$

where $\left\langle x_{g}\right\rangle$ is the median and IQR is the normalized interquartile range of the expression value of a single gene across regions. Normalized gene expression values were then rescaled to a unit interval:

$$
x_{\text {scaled }}=\frac{x_{\text {norm }}-\min \left(x_{\text {norm }}\right)}{\max \left(x_{\text {norm }}\right)-\min \left(x_{\text {norm }}\right)}
$$

Gene expression values were normalized across tissue samples using the same procedure. Samples assigned to the same brain region were then averaged separately for each donor. Scaled regional expression profiles were finally averaged across donors.

\section{Gene-receptor pairs}

With the notable exception of the $\mathrm{GABA}_{B}$ receptor, metabotropic neurotransmitter receptors are monomeric structures, and thus a single gene codes for the entire receptor. Therefore, the expression of the receptor-coding gene was correlated with the density of the receptor itself. The $\mathrm{GABA}_{B}$ and ionotropic receptors are characterized by being multimeric protein complexes, so each receptor was correlated with microarray expression of all possible receptor subunits. Below, we outline each multimeric case.

- $\mathrm{GABA}_{\mathrm{A}}$ is a pentamer typically composed of three primary subunits $\left(\alpha_{1}, \beta_{2}\right.$, and $\left.\gamma_{2}\right)$ but can be built out of a total of nineteen different subunits. For simplicity, we show results for the three primary subunits in the main text, but results for the remaining sixteen subunits can be found in Fig. S2.

- $\mathrm{GABA}_{\mathrm{B}}$, a multimeric metabotropic receptor, is composed of two subunits. We show both in the main analyses.

- AMPA is a heterotetramer that typically consists of two pairs of duplicate subunits. These two pairs can be formed from any combination of four subunits. We show results for the gene whose expression is most highly correlated with AMPA density in the main text (GRIA1).

- NMDA is also a heterotetramer, typically composed of two N1 and two N2 subunits, although there are four different $N 2$-encoding genes, as well as a third subunit (N3) for which there are two subunitencoding genes. The main analyses use the expression of the N1-encoding gene (GRIN1).

- Kainate exists as both a homotetramer and heterotetramer, built from any of five subunits. We show results for the gene whose expression is most highly correlated with kainate density in the main text (GRIK2).

- $\alpha_{4} \beta_{2}$ is a pentamer typically composed of two $\alpha_{4}$ subunits and three $\beta_{2}$ subunits [19]. However, the ligand used for the autoradiograph, epibatidin, binds to any heteromeric nicotinic receptors that contain both an alpha subunit $\left(\alpha_{2}-\alpha_{7}, \alpha_{9}, \alpha_{10}\right)$ and a beta subunit $\left(\beta_{2}-\beta_{4}\right)$. The most abundant such receptor in the brain is the $\alpha_{4} \beta_{2}$ receptor, so we focus on gene expression of the $\alpha_{4}$ and $\beta_{2}$ subunits (CHRNA4 and CHRNB2, respectively) in the main text.

Correlations between neurotransmitter receptor density and multiple subunit expression were corrected for multiple comparisons using the Benjamini-Hochberg FDR correction [11]. Correlation coefficients and corrected $p$-values (see Null model) for all subunits can be found in Supplementary Table 3 (PET) and Supplementary Table 4 (autoradiography).

\section{Null model}

Spatial autocorrelation-preserving permutation tests were used to assess statistical significance of associations across brain regions, termed "spin tests" [2, 48]. Parametric $p$-values were not used because spatially embedded systems such as the brain violate the assumption that observations (brain regions) are independent from one another. We created a surface-based representation of the parcellation on the FreeSurfer fsaverage surface, via files from the Connectome Mapper toolkit (https://github.com/LTS5/cmp). We used the spherical projection of the fsaverage surface to define spatial coordinates for each parcel by selecting the coordinates of the vertex closest to the center of the mass of each parcel [85]. These parcel coordinates were then randomly rotated, and original parcels were reassigned the value of the closest rotated parcel (10 000 repetitions). Parcels for which the medial wall was closest were assigned the value of the next most proximal parcel instead. The procedure was performed at the parcel resolution rather 

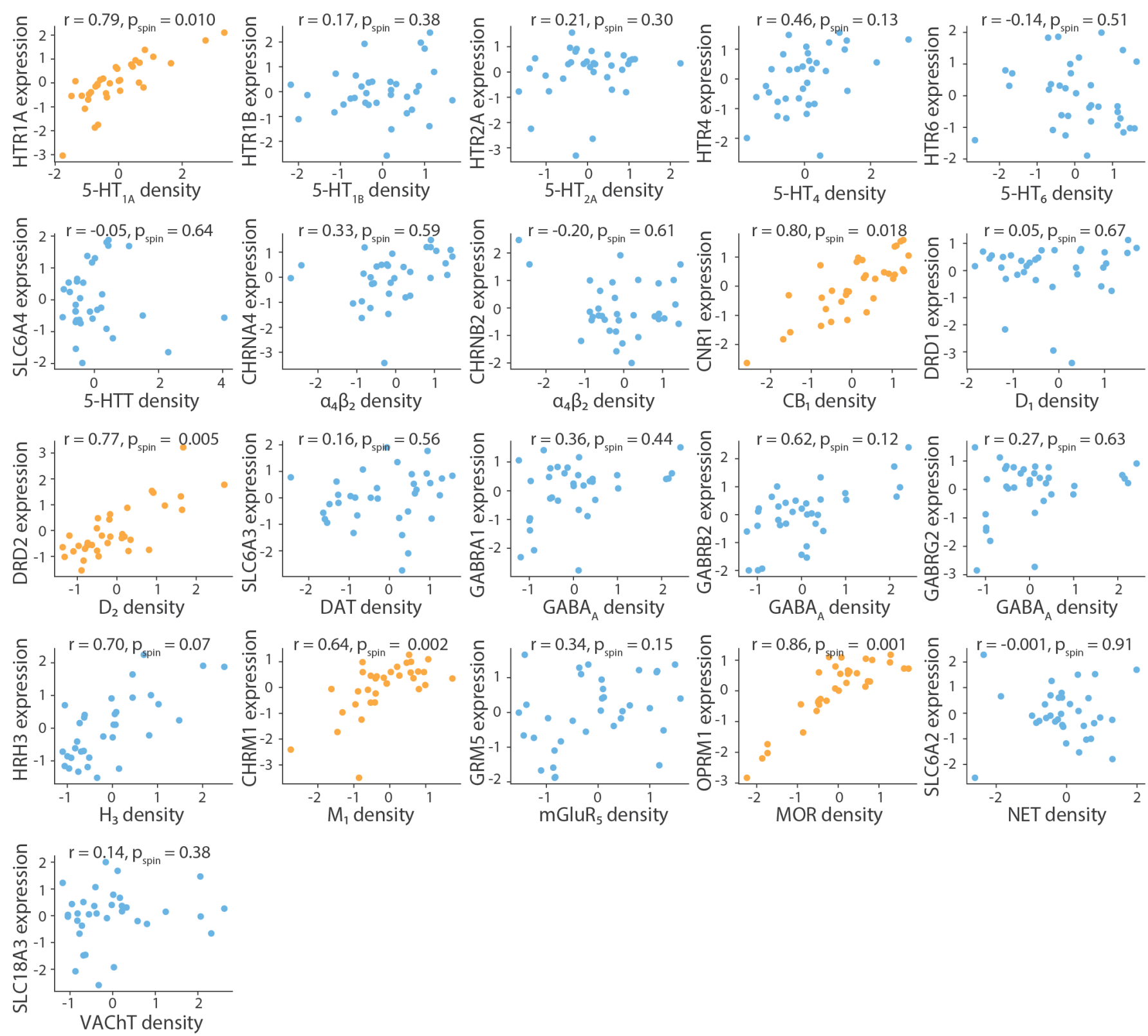

Figure 1. PET-derived receptor/transporter densities versus gene expression | PET tracer maps for 18 different neurotransmitter receptors and transports reveal that the density of only five neurotransmitter receptors correlates significantly with the expression of their corresponding gene, across 34 Desikan Killiany regions in the left cortex. Yellow scatter plots indicate significant density-expression correspondence, against an autocorrelation-preserving null model. All receptor densities are z-scored.

than the vertex resolution to avoid upsampling the data, and only to the left hemisphere. In the autoradiography dataset, null correlations were computed ignoring the insula and regions resampled to the insula, for a maximum of three ignored brain regions.

\section{RESULTS}

Using the group-averaged healthy control PET-derived neurotransmitter receptor and transporter densities, we find that in almost all cases, there is no significant correlation between receptor density and receptor gene expression (Fig. 1; for results in the subcortex see Fig. S1). Indeed, only five single-protein inhibitory metabotropic receptors (5- $\mathrm{HT}_{1 \mathrm{~A}}, \mathrm{D}_{2}, \mathrm{CB}_{1}, \mathrm{M}_{1}$ and $\mathrm{MOR}$ ) show significant relationships $\left(p_{\text {spin }}<0.05\right)$ with the expression of their corresponding genes (HTR1A, DRD2, CRN1, CHRM1, and OPRM1, respectively). Notably, consistent with previous reports, the $\mathrm{GABA}_{\mathrm{A}}$ receptor is positively correlated $(r>0.6)$ with the expression of its $\beta_{2}$ subunit, and negatively correlated $(r<-0.6)$ with the ex- 

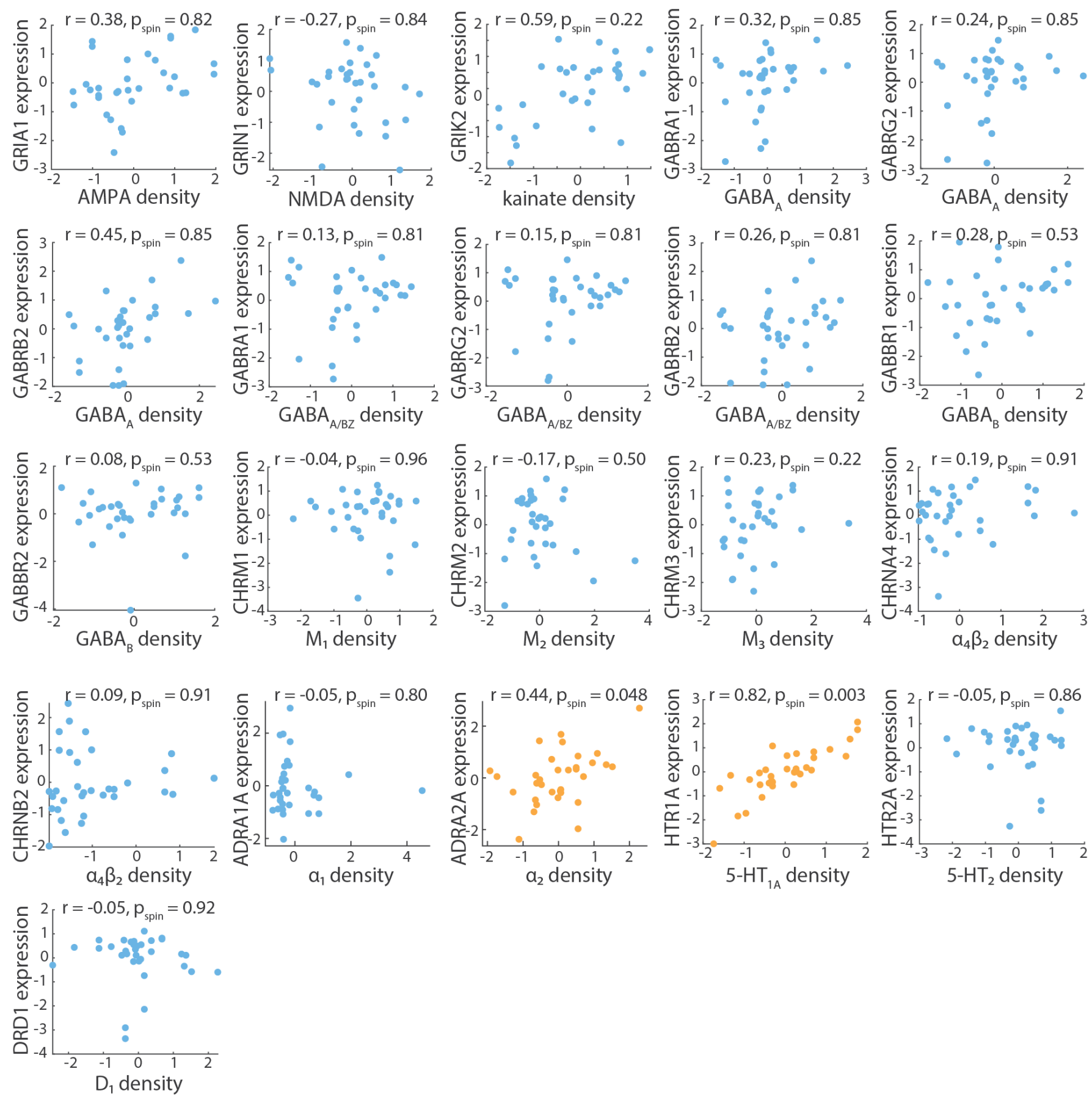

Figure 2. Autoradiography-derived receptor densities versus gene expression | Autoradiographs for 15 different neurotransmitter receptors reveal that only 5- $\mathrm{HT}_{1 \mathrm{~A}}$ and $\alpha_{2}$ correlate significantly with the expression of their corresponding genes (HTR1A and $A D R A 2 A$, respectively), across 33 Desikan Killiany regions in the left cortex. Yellow scatter plots indicate significant densityexpression correspondence, against an autocorrelation-preserving null model. All receptor densities are z-scored.

pression of its $\alpha_{3}, \alpha_{5}, \beta_{1}$, and $\gamma_{1}[53,58]$, although these relationships are not significant after correcting for multiple comparisons (see Fig. S2 for scatter plots with remaining $\mathrm{GABA}_{\mathrm{A}}$ subunits and Supplementary Table 3 for reported Pearson's $r$ and corrected $p$-values; [11]). Similarly, using the autoradiography dataset, we find that in almost all cases, gene expression is a poor approximator of neurotransmitter receptor density (Fig. 2). We again find a close correspondence between $5-\mathrm{HT}_{1 \mathrm{~A}}$ and the expression of HTR1A $\left(r=0.82, p_{\text {spin }}=0.002\right)$. However, unlike what was observed with the PET dataset, $\mathrm{M}_{1}$ does not show significant correlations with CHRM1. We addi- 
a | PET

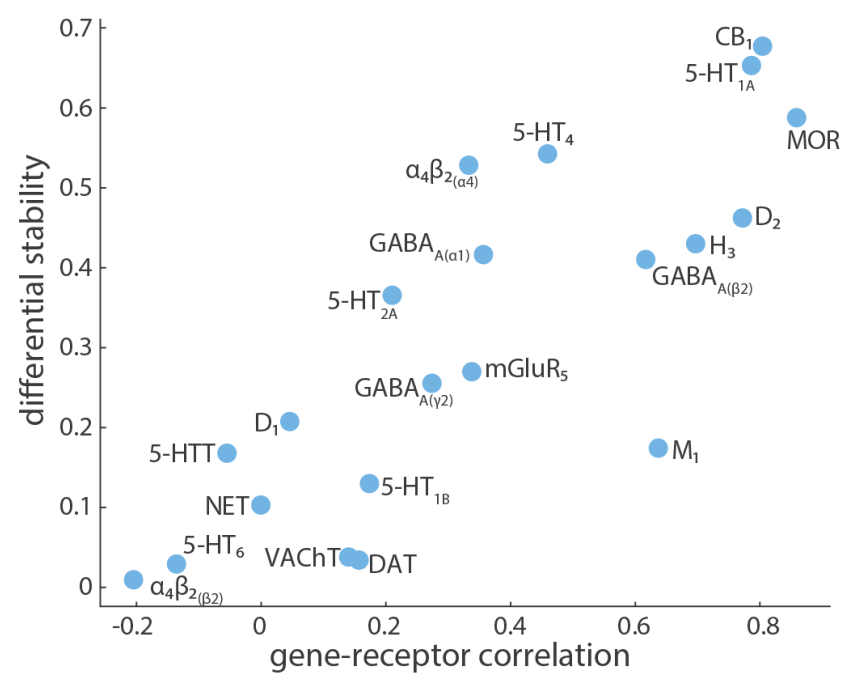

b | autoradiography

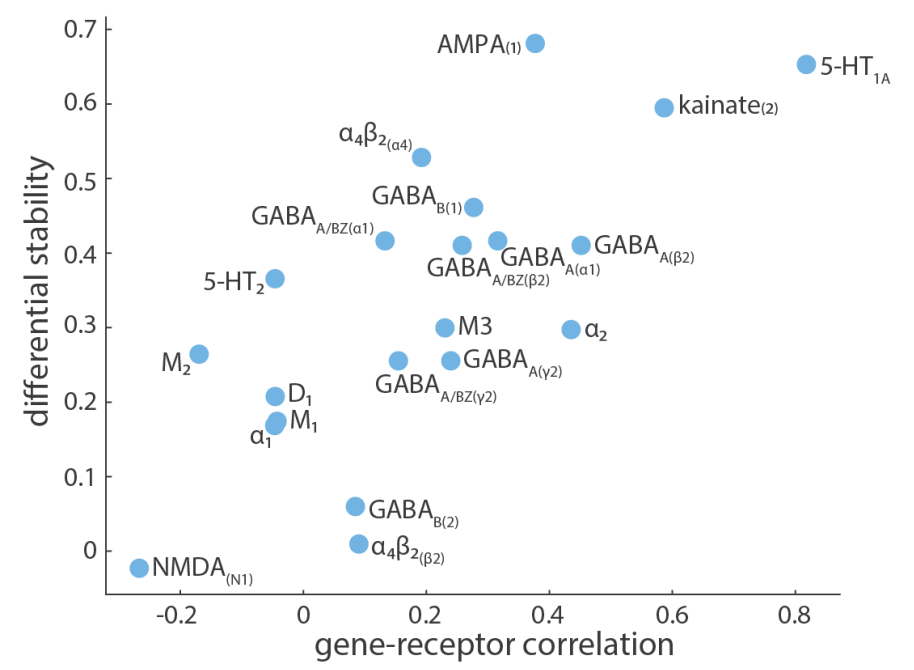

Figure 3. Differentially stable genes are more correlated with neurotransmitter receptor density | We find that differential stability, a measure of the variability of a gene's expression across donors, is significantly correlated with gene-receptor correlations when using (a) PET-derived receptor/transporter densities $\left(r=0.82, p=5 \times 10^{-6}\right)$ and (b) autoradiography-derived receptor densities $(r=0.74, p=0.0001)$. Labels are neurotransmitter receptors/transporters, and suffixes in parentheses are relevant subunits.

tionally find a significant correlation between $\alpha_{2}$ receptor density and ADRA2A gene expression, although the effect is less apparent. No other neurotransmitter receptor besides $5-\mathrm{HT}_{1 \mathrm{~A}}$ in the autoradiography dataset has a close correspondence between receptor density and gene expression.

To ensure results are not influenced by the choice of brain parcellation, we repeated the PET analyses in a finer parcellation of 111 left hemisphere cortical regions (Fig. S3; [17]). At this higher resolution, we find that $5-\mathrm{HT}_{1 \mathrm{~A}}, \mathrm{D}_{2}, \mathrm{CB}_{1}$, and MOR still show close correspondences with their associated genes, although $\mathrm{CB}_{1}$ 's correlation has dropped to $r=0.66$. $\mathrm{M}_{1}$ is still significantly correlated to CHRM1 although to a lesser degree $\left(r=0.35, p_{\text {spin }}=0.017\right)$. Furthermore, we find an additional significantly-correlated gene-receptor pair (GRM5-mGluR $\left.5=0.44, p_{\text {spin }}=0.008\right)$. Altogether, $5-\mathrm{HT}_{1 \mathrm{~A}}, \mathrm{D}_{2}, \mathrm{CB}_{1}$, and MOR show stable and high expression-density correspondence across both spatial scales and imaging modalities.

We next sought to understand why certain neurotransmitter receptors demonstrate expression-density correspondence, whereas other receptors, and all transporters, show no expression-density correspondence. Since group-averaged measures of gene expression and receptor/transporter density come from disjoint samples of participants, we hypothesized that genes with greater variability between participants would show weaker correlations with group-averaged neurotransmitter receptor and transporter densities. To test this, we used each gene's differential stability, a measure of gene expression variability across the six donors (see Methods for de- tails [36]). Fig. 3a reveals that genes with greater differential stability, and therefore less inter-subject variance, are generally more correlated with PET-derived receptor density $\left(r=0.82, p=4 \times 10^{-6}\right)$. When we repeated the analyses in the autoradiography dataset, we find a similar trend ( $r=0.74, p=0.0001$; Fig. 3b).

The previous analyses were conducted across the full left hemisphere, but it is possible that genereceptor/transporter coupling is variable across cortex. Since receptor distributions covary with cognitive functional activations along a sensory-fugal gradient $[27,34$, $35]$, we tested whether gene expression is correlated with receptor densities across the four Mesulam classes of laminar differentiation (Fig. 4; [51, 61]). This analysis was done using the 111-region left hemisphere parcellation to ensure sufficient data observations in each laminar class. Interestingly, we find that receptors whose density is highly correlated with gene expression may show poor association in specific classes. Indeed, 5$\mathrm{HT}_{1 \mathrm{~A}}$ and $\mathrm{D}_{2}$ receptor density is highly correlated with expression in all laminar classes except idiotypic, which includes primary sensory-motor regions. The remaining receptors and transporters show large expression-density correlation variability across laminar classes. For example, $5-\mathrm{HT}_{6}$ is consistently poorly correlated with HTR6 gene expression no matter the laminar class $(|r|<0.13)$, whereas the $G_{A B A}$ receptor is highly correlated with GABRB2 expression in idiotypic areas $(r=0.62)$ but weakly correlated in heteromodal and paralimbic areas $\left(r_{\mathrm{plmb}}=-0.10, r_{\text {het }}=0.02\right)$. Meanwhile, dopamine receptor $\mathrm{D}_{1}$ is positively correlated with $D R D 1$ expression in paralimbic areas $(r=0.30)$, negatively correlated in 


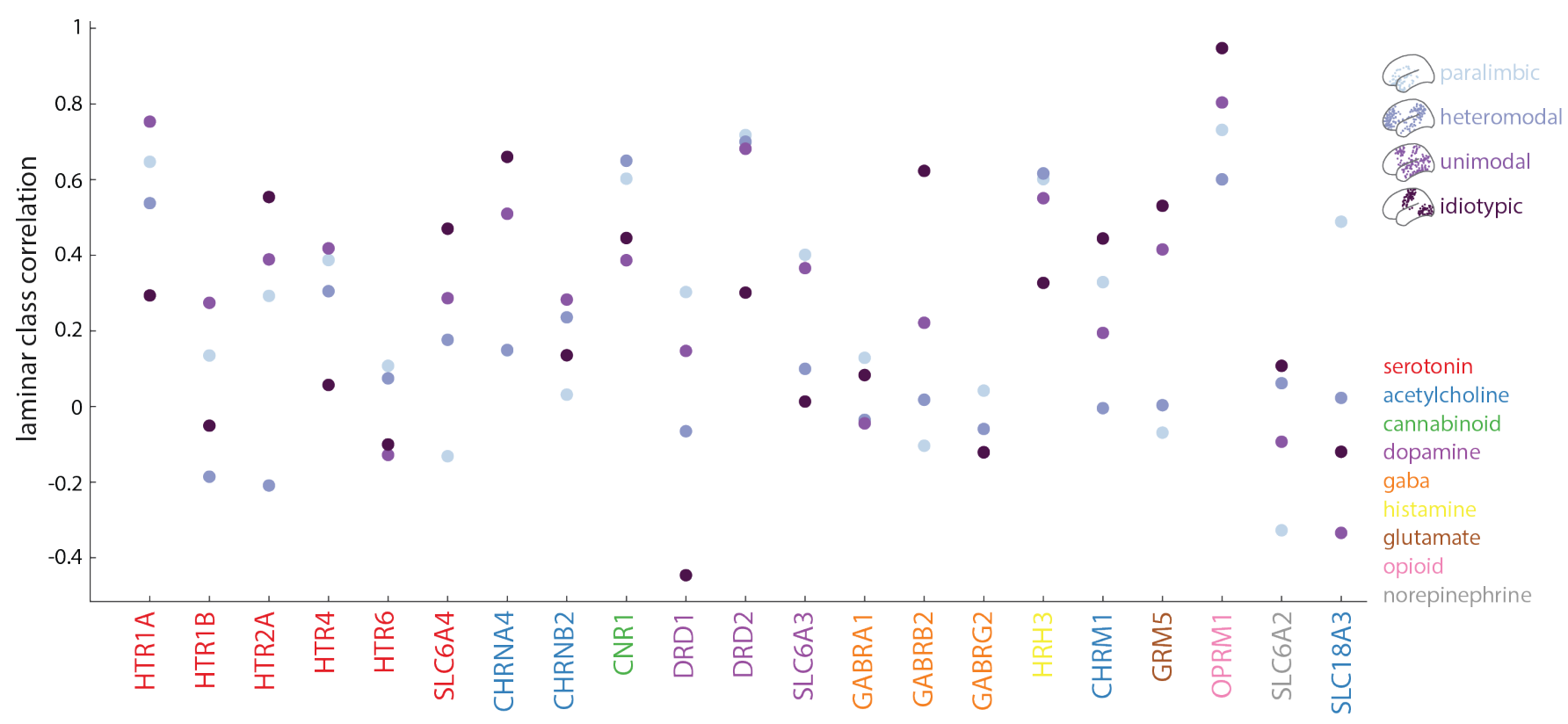

Figure 4. Gene-receptor/transporter correspondence varies across Mesulam classes of laminar differentiation | PET-derived receptor/transporter densities were correlated to gene expression within four classes of laminar differentiation [51, 61]. For each receptor and transporter, the density-expression correlation within each laminar class is plotted. Gene names are coloured by neurotransmitter system.

idiotypic areas $(r=-0.45)$, and not correlated in intermediate areas $(|r|<0.15)$. Altogether, we find that the correspondence between gene expression and receptor density is itself variable across the cortex and differs between laminar classes and cognitive systems $[60,90]$.

\section{DISCUSSION}

Understanding how the chemoarchitecture of the brain modulates the link between structure and function requires accurate and comprehensive regional neurotransmitter receptor and transporter profiles. Here we formally test whether there is a correlation between gene expression and neurotransmitter receptor/transporter density, for a total of 27 unique neurotransmitter receptors, receptor binding sites, and transporters, from both PET images and autoradiographs. We find that only four receptors $\left(5-\mathrm{HT}_{1 \mathrm{~A}}, \mathrm{D}_{2}, \mathrm{CB}_{1}\right.$, and $\left.\mathrm{MOR}\right)$ display a close spatial correspondence between gene expression levels and receptor densities. We therefore conclude that researchers should exercise caution when using gene expression as a proxy for receptor and transporter densities.

We note that the lack of correlation between protein levels and the levels of their coding mRNA is not unreasonable as there are many mechanisms that may affect the protein-mRNA correlation. First, levels of mRNA detected on the microarray do not take into account the transcript isoforms that can be produced from the same gene, nor the stability of the resulting mRNA, which are determined by mRNA modifications such as splicing $[46,86]$. Second, the proportion of different cell types in a microarray sample may distort the gene expression-protein density correspondence due to differences in the proteome and transcriptome, including different splice variant expression [78, 89]. Third, studies in bacteria [45] and mice [40] have demonstrated that rate of protein synthesis also alters protein levels. Fourth, protein buffering dampens the effect of variations in gene expression levels, including an adaptation of protein turnover through protein degradation, and the modulated activity of protein transport machinery which determines the final subcellular localization of the protein $[7,46,77,87]$. Altogether, the variation in the activity of these processes may contribute to the observed difference in levels of mRNA expression and protein abundance of receptors/transporters in the cortex.

Nonetheless, we do find a small subset of neurotransmitter receptors that demonstrate close gene transcription-receptor density relationships. One possible explanation is rooted in population variance of gene expression and receptor densities. Since both receptor densities and gene expression are averaged across participants, genes and receptors with low inter-subject variability across the population would be better captured by the group-averaged map used in the present analyses. This is supported by the fact that neurotransmitter receptor densities are more correlated with genes that are more stable across donors (Fig. 3). A second nonexclusive explanation is that the steps between gene transcription and membrane insertion are potentially more 
preserved for specific neurotransmitter receptors. Indeed, the correspondence between gene expression and receptor density would depend on localization of the mRNA due to differences in ribosome and tRNA availability [12], as well as protein turnover rates at the location the receptor is expressed [13]. Additionally, receptor systems that are phylogenetically older, involved in functions that require rigid stimulus-response relationships, or more fundamental to the organizational principles of the brain, may demonstrate more robust translation that manifest as close expression-density associations. For example, in the mouse cortex, gene expression for certain interneuron cell types are closely aligned with gradients of cortical organization [30]. Interestingly, the gene that most recapitulates this organizational feature (Pvalb) is highly correlated to its corresponding protein's density (parvalbumin; Spearman $r=0.95$ ), whereas Sst-an interneuron marker that is poorly aligned with cortical organization-is poorly correlated with somatostatin density (Spearman $r=0.24, p=0.1$ ) [28].

In the present report, we caution against the use of gene expression as a proxy for receptor densities, and recommend using techniques that more directly capture receptor distributions such as PET or autoradiography. However, we note that both PET and autoradiography have specific challenges. For example, PET tracers are generally only sensitive to receptors on the cell surface, but neurotransmitter receptors are also found within the cell [75]. Furthermore, PET does not directly measure density, is sensitive to in-scanner motion, and may demonstrate non-specific binding [26]. Meanwhile, autoradiographs more directly measure receptor densities but are only acquired post-mortem, are more expensive and labor intensive, and measure densities in discrete brain sections [92]. Although it is encouraging that we find consistent results across PET- and autoradiographyderived receptor densities, future research is needed to accurately and comprehensively measure neurotransmitter receptor densities throughout the brain.

Our results build on previous work that explores the expression-density relationship of specific neurotransmitter systems or receptors, such as the serotonergic system $[10,43]$, the $\mathrm{GABA}_{\mathrm{A}}$ receptor [58], and the opioid system $[43,69]$, using PET and/or autoradiographyderived density. The present report comprehensively investigates the expression-density correspondence for 27 unique neurotransmitter receptors, receptor binding sites, and transporters across 9 different neurotransmitter systems using both PET and autoradiography measurements. Here we note some consistencies and inconsistencies across findings. Consistencies include: (1) high correlation between $5-\mathrm{HT}_{1 \mathrm{~A}}$ density and HTR1A expression $[10,43,69]$, (2) weaker associations for other serotonergic receptors [10], (3) high correlation between MOR and $O P R M_{1}$ [43], and (4) positive correlation between GABA $A_{A}$ density and $\beta_{2}$ subunit expression, but negative correlation between $\mathrm{GABA}_{\mathrm{A}}$ density and $\gamma_{1}$ subunit expression-although we do not find that these relationships are significant after correcting for multiple comparisons [58]. On the other hand, we find no association between $\mathrm{GABA}_{\mathrm{A}}$ density and the expression of $\alpha_{1}$ and $\gamma_{2}$ main channel subunits, unlike that reported in [58]. Additionally, [69] find that the PET tracer dipenorphine, which binds to all three opioid subtypes $(\delta, \kappa$, and $\mu$ ), is not correlated with the expression of any opioid subtype. Meanwhile, we find a strong correlation between MOR density and OPRM1 expression, and presume that expression-density relationships are specific to single receptors and not generalizable across receptors in the same neurotransmitter system. We note that these inconsistencies are likely related to the gene normalization method, a key processing step with large effects on estimated gene expression [47].

We close with some methodological considerations when working with PET, autoradiography, and gene expression datasets. First, gene expression estimates are derived from only six post-mortem human brains. Although the Allen Human Brain Atlas is a state-of-theart dataset of microarray gene expression, more comprehensive datasets are necessary to confirm gene expression levels. Second, measures of neurotransmitter receptor/transporter densities and gene expression are acquired in different individuals, so we are not able to make conclusions on the correspondence between gene expression and receptor/transporter density in the same cell tissue. Third, due to the relatively coarser resolution of PET, and the incomplete spatial coverage of autoradiography, main analyses were conducted in a parcellation of only 33-34 left hemisphere cortical brain regions. Replication in a finer parcellation for the PET receptor data do show similar results (Fig. S3), as well as high receptor density correlation between hemispheres, but high resolution whole-brain gene-receptor/transporter analyses should be conducted in future work.

In summary, we find that the expression of specific receptor/transporter-coding genes can generally not be used to estimate neurotransmitter receptor and transporter density. We only find a correspondence between gene expression and receptor density for $5-\mathrm{HT}_{1 \mathrm{~A}}, \mathrm{D}_{2}$, $\mathrm{CB}_{1}$, and MOR. Future efforts to map neurotransmitter receptor and transporter profiles to brain structure and function should verify the expression-density association when using microarray gene expression in place of receptor and transporter density.

\section{Acknowledgments}

We thank Kelly Smart, Sylvia Cox, Yanjun Wu, JeanDominique Gallezot, Étienne Aumont, Stijn Servaes, Stephanie G. Scala, Jonathan M. DuBois, Gleb Bezgin, Taylor W. Schmitz, R. Nathan Spreng, Jean-Paul Soucy, Synthia Guimond, Jarmo Hietala, Marc-André Bédard, Marco Leyton, Eliane Kobayashi, Pedro Rosa-Neto, and Richard E. Carson for collecting and sharing the PET data presented here. We thank Vincent Bazinet, Zhen-Qi Liu, 
Filip Milisav, Laura Suarez, Bertha Vazquez-Rodriguez, and Mingze Li for their comments and suggestions on the manuscript. This research was undertaken thanks in part to funding from the Canada First Research Excellence Fund, awarded to McGill University for the Healthy Brains for Healthy Lives initiative. BM acknowledges support from the Natural Sciences and Engineering Research Council of Canada (NSERC Discovery Grant RG-
PIN \#017-04265) and from the Canada Research Chairs Program. JYH acknowledges support from the Helmholtz International BigBrain Analytics \& Learning Laboratory, the Natural Sciences and Engineering Research Council of Canada, and the Fonds de reserches de Québec. The funders had no role in study design, data collection and analysis, decision to publish or preparation of the manuscript.
[1] Aghourian, M., Legault-Denis, C., Soucy, J., Rosa-Neto, P., Gauthier, S., Kostikov, A., Gravel, P., and Bedard, M. (2017). Quantification of brain cholinergic denervation in alzheimer's disease using pet imaging with [18 f]-feobv. Molecular psychiatry, 22(11):1531-1538.

[2] Alexander-Bloch, A. F., Shou, H., Liu, S., Satterthwaite, T. D., Glahn, D. C., Shinohara, R. T., Vandekar, S. N., and Raznahan, A. (2018). On testing for spatial correspondence between maps of human brain structure and function. NeuroImage, 178:540-551.

[3] Arnatkevičiūtè, A., Fulcher, B. D., and Fornito, A. (2019). A practical guide to linking brain-wide gene expression and neuroimaging data. Neuroimage, 189:353-367.

[4] Baldassarri, S. R., Hillmer, A. T., Anderson, J. M., Jatlow, P., Nabulsi, N., Labaree, D., Cosgrove, K. P., O’Malley, S. S., Eissenberg, T., Krishnan-Sarin, S., et al. (2018). Use of electronic cigarettes leads to significant beta2-nicotinic acetylcholine receptor occupancy: evidence from a pet imaging study. Nicotine and Tobacco Research, 20(4):425433.

[5] Baldassarri, S. R., Park, E., Finnema, S. J., Planeta, B., Nabulsi, N., Najafzadeh, S., Ropchan, J., Huang, Y., Hannestad, J., Maloney, K., et al. (2020). Inverse changes in raphe and cortical 5-ht1b receptor availability after acute tryptophan depletion in healthy human subjects. Synapse, 74(10):e22159.

[6] Ballentine, G., Friedman, S. F., and Bzdok, D. (2021). Trips and neurotransmitters: Discovering principled patterns across 6,850 hallucinogenic experiences. bioRxiv.

[7] Battle, A., Khan, Z., Wang, S. H., Mitrano, A., Ford, M. J., Pritchard, J. K., and Gilad, Y. (2015). Impact of regulatory variation from rna to protein. Science, 347(6222):664667.

[8] Bedard, M.-A., Aghourian, M., Legault-Denis, C., Postuma, R. B., Soucy, J.-P., Gagnon, J.-F., Pelletier, A., and Montplaisir, J. (2019). Brain cholinergic alterations in idiopathic rem sleep behaviour disorder: a pet imaging study with 18f-feobv. Sleep medicine, 58:35-41.

[9] Belfort-DeAguiar, R., Gallezot, J.-D., Hwang, J. J., Elshafie, A., Yeckel, C. W., Chan, O., Carson, R. E., Ding, Y.-S., and Sherwin, R. S. (2018). Noradrenergic activity in the human brain: a mechanism supporting the defense against hypoglycemia. The Journal of Clinical Endocrinology \& Metabolism, 103(6):2244-2252.

[10] Beliveau, V., Ganz, M., Feng, L., Ozenne, B., Højgaard, L., Fisher, P. M., Svarer, C., Greve, D. N., and Knudsen, G. M. (2017). A high-resolution in vivo atlas of the human brain's serotonin system. Journal of Neuroscience, 37(1):120-128.

[11] Benjamini, Y. and Hochberg, Y. (1995). Controlling the false discovery rate: a practical and powerful approach to multiple testing. J Roy Stat Soc B, 57(1):289-300.

[12] Besse, F. and Ephrussi, A. (2008). Translational control of localized mrnas: restricting protein synthesis in space and time. Nature reviews Molecular cell biology, 9(12):971980.

[13] Boisvert, F.-M., Ahmad, Y., Gierliński, M., Charrière, F., Lamont, D., Scott, M., Barton, G., and Lamond, A. I. (2012). A quantitative spatial proteomics analysis of proteome turnover in human cells. Molecular \& Cellular Proteomics, 11(3).

[14] Braun, U., Harneit, A., Pergola, G., Menara, T., Schäfer, A., Betzel, R. F., Zang, Z., Schweiger, J. I., Zhang, X., Schwarz, K., et al. (2021). Brain network dynamics during working memory are modulated by dopamine and diminished in schizophrenia. Nature Communications, 12(1):1-11.

[15] Burt, J. B., Demirtaş, M., Eckner, W. J., Navejar, N. M., Ji, J. L., Martin, W. J., Bernacchia, A., Anticevic, A., and Murray, J. D. (2018). Hierarchy of transcriptomic specialization across human cortex captured by structural neuroimaging topography. Nature neuroscience, 21(9):12511259.

[16] Burt, J. B., Preller, K. H., Demirtas, M., Ji, J. L., Krystal, J. H., Vollenweider, F. X., Anticevic, A., and Murray, J. D. (2021). Transcriptomics-informed large-scale cortical model captures topography of pharmacological neuroimaging effects of lsd. bioRxiv.

[17] Cammoun, L., Gigandet, X., Meskaldji, D., Thiran, J. P., Sporns, O., Do, K. Q., Maeder, P., Meuli, R., and Hagmann, P. (2012). Mapping the human connectome at multiple scales with diffusion spectrum mri. J Neurosci Meth, 203(2):386-397.

[18] Chiang-shan, R. L., Potenza, M. N., Lee, D. E., Planeta, B., Gallezot, J.-D., Labaree, D., Henry, S., Nabulsi, N., Sinha, R., Ding, Y.-S., et al. (2014). Decreased norepinephrine transporter availability in obesity: positron emission tomography imaging with (s, s)-[11c] o-methylreboxetine. Neuroimage, 86:306-310.

[19] Dani, J. A. (2015). Neuronal nicotinic acetylcholine receptor structure and function and response to nicotine. International review of neurobiology, 124:3-19.

[20] Deco, G., Aquino, K. M., Arnatkeviciute, A., Oldham, S., Sabaroedin, K., Rogasch, N. C., Kringelbach, M. L., and Fornito, A. (2020). Dynamical consequences of regional heterogeneity in the brains transcriptional landscape. bioRxiv.

[21] Desikan, R. S., Ségonne, F., Fischl, B., Quinn, B. T., Dickerson, B. C., Blacker, D., Buckner, R. L., Dale, A. M., Maguire, R. P., Hyman, B. T., et al. (2006). An automated labeling system for subdividing the human cerebral cortex on mri scans into gyral based regions of interest. NeuroIm- 
age, 31(3):968-980.

[22] Ding, Y.-S., Singhal, T., Planeta-Wilson, B., Gallezot, J.-D., Nabulsi, N., Labaree, D., Ropchan, J., Henry, S., Williams, W., Carson, R. E., et al. (2010). Pet imaging of the effects of age and cocaine on the norepinephrine transporter in the human brain using $(\mathrm{s}, \mathrm{s})$-[11c] o-methylreboxetine and hrrt. Synapse, 64(1):30-38.

[23] DuBois, J. M., Rousset, O. G., Rowley, J., PorrasBetancourt, M., Reader, A. J., Labbe, A., Massarweh, G., Soucy, J.-P., Rosa-Neto, P., and Kobayashi, E. (2016). Characterization of age/sex and the regional distribution of mglur5 availability in the healthy human brain measured by high-resolution [11 c] abp688 pet. European journal of nuclear medicine and molecular imaging, 43(1):152-162.

[24] Dukart, J., Holiga, Š., Chatham, C., Hawkins, P., Forsyth, A., McMillan, R., Myers, J., Lingford-Hughes, A. R., Nutt, D. J., Merlo-Pich, E., et al. (2018). Cerebral blood flow predicts differential neurotransmitter activity. Scientific reports, 8(1):1-11.

[25] D'Souza, D. C., Cortes-Briones, J. A., Ranganathan, M., Thurnauer, H., Creatura, G., Surti, T., Planeta, B., Neumeister, A., Pittman, B., Normandin, M. D., et al. (2016). Rapid changes in cannabinoid 1 receptor availability in cannabis-dependent male subjects after abstinence from cannabis. Biological psychiatry: cognitive neuroscience and neuroimaging, 1(1):60-67.

[26] Ekelund, J., Slifstein, M., Narendran, R., Guillin, O., Belani, H., Guo, N.-N., Hwang, Y., Hwang, D.-R., AbiDargham, A., and Laruelle, M. (2007). In vivo da d 1 receptor selectivity of nnc 112 and sch 23390. Molecular imaging and biology, 9(3):117-125.

[27] Froudist-Walsh, S., Xu, T., Niu, M., Rapan, L., Zilles, K., Margulies, D. S., Wang, X.-J., and Palomero-Gallagher, N. (2021). Gradients of receptor expression in the macaque cortex. bioRxiv.

[28] Fulcher, B. D. (2019). Discovering conserved properties of brain organization through multimodal integration and interspecies comparison. Journal of experimental neuroscience, 13:1179069519862047.

[29] Fulcher, B. D. and Fornito, A. (2016). A transcriptional signature of hub connectivity in the mouse connectome. Proc Natl Acad Sci USA, 113(5):1435-1440.

[30] Fulcher, B. D., Murray, J. D., Zerbi, V., and Wang, X.-J. (2019). Multimodal gradients across mouse cortex. Proc Natl Acad Sci USA, 116(10):4689-4695.

[31] Gallezot, J.-D., Nabulsi, N., Neumeister, A., PlanetaWilson, B., Williams, W. A., Singhal, T., Kim, S., Maguire, R. P., McCarthy, T., Frost, J. J., et al. (2010). Kinetic modeling of the serotonin 5-ht1b receptor radioligand [11c] p943 in humans. Journal of Cerebral Blood Flow \& Metabolism, 30(1):196-210.

[32] Gallezot, J.-D., Planeta, B., Nabulsi, N., Palumbo, D., Li, X., Liu, J., Rowinski, C., Chidsey, K., Labaree, D., Ropchan, J., et al. (2017). Determination of receptor occupancy in the presence of mass dose:[11c] gsk189254 pet imaging of histamine h3 receptor occupancy by pf03654746. Journal of Cerebral Blood Flow \& Metabolism, 37(3):1095-1107.

[33] Gao, R., van den Brink, R. L., Pfeffer, T., and Voytek, B. (2020). Neuronal timescales are functionally dynamic and shaped by cortical microarchitecture. Elife, 9:e61277.

[34] Goulas, A., Changeux, J.-P., Wagstyl, K., Amunts, K., Palomero-Gallagher, N., and Hilgetag, C. C. (2021). The natural axis of transmitter receptor distribution in the human cerebral cortex. Proceedings of the National Academy of Sciences, 118(3).

[35] Hansen, J. Y., Shafiei, G., Markello, R. D., Smart, K., Cox, S., Wu, Y., Gallezot, J.-D., Étienne, A., Servaes, S., Scala, S. G., DuBois, J. M., Wainstein, G., Bezgin, G., Funck, T., Schmitz, T. W., Spreng, R. N., Soucy, J.-P., Baillet, S., Guimond, S., Hietala, J., Bédard, M.-A., Leyton, M., Kobayashi, E., Rosa-Neto, P., Palomero-Gallagher, N., Shine, J. M., Carson, R. E., Tuominen, L., Dagher, A., and Misic, B. (2021). Mapping neurotransmitter systems to the structural and functional organization of the human neocortex. bioRxiv.

[36] Hawrylycz, M., Miller, J. A., Menon, V., Feng, D., Dolbeare, T., Guillozet-Bongaarts, A. L., Jegga, A. G., Aronow, B. J., Lee, C.-K., Bernard, A., et al. (2015). Canonical genetic signatures of the adult human brain Nat Neurosci, 18(12):1832.

[37] Hawrylycz, M. J., Lein, E. S., Guillozet-Bongaarts, A. L., Shen, E. H., Ng, L., Miller, J. A., Van De Lagemaat, L. N., Smith, K. A., Ebbert, A., Riley, Z. L., et al. (2012). An anatomically comprehensive atlas of the adult human brain transcriptome. Nature, 489(7416):391.

[38] Hillmer, A. T., Esterlis, I., Gallezot, J.-D., Bois, F., Zheng, M.-Q., Nabulsi, N., Lin, S.-F., Papke, R., Huang, Y., Sabri, O., et al. (2016). Imaging of cerebral $\alpha 4 \beta 2 *$ nicotinic acetylcholine receptors with (-)-[18f] flubatine pet: Implementation of bolus plus constant infusion and sensitivity to acetylcholine in human brain. Neuroimage, 141:7180.

[39] Hoftman, G. D., Dienel, S. J., Bazmi, H. H., Zhang, Y., Chen, K., and Lewis, D. A. (2018). Altered gradients of glutamate and gamma-aminobutyric acid transcripts in the cortical visuospatial working memory network in schizophrenia. Biological psychiatry, 83(8):670-679.

[40] Jovanovic, M., Rooney, M. S., Mertins, P., Przybylski, D., Chevrier, N., Satija, R., Rodriguez, E. H., Fields, A. P., Schwartz, S., Raychowdhury, R., et al. (2015). Dynamic profiling of the protein life cycle in response to pathogens. Science, 347(6226).

[41] Kaller, S., Rullmann, M., Patt, M., Becker, G.-A., Luthardt, J., Girbardt, J., Meyer, P. M., Werner, P., Barthel, H., Bresch, A., et al. (2017). Test-retest measurements of dopamine d 1-type receptors using simultaneous pet/mri imaging. European journal of nuclear medicine and molecular imaging, 44(6):1025-1032.

[42] Kantonen, T., Karjalainen, T., Isojärvi, J., Nuutila, P., Tuisku, J., Rinne, J., Hietala, J., Kaasinen, V., Kalliokoski, K., Scheinin, H., et al. (2020). Interindividual variability and lateralization of $\mu$-opioid receptors in the human brain. NeuroImage, 217:116922.

[43] Komorowski, A., James, G., Philippe, C., Gryglewski, G., Bauer, A., Hienert, M., Spies, M., Kautzky, A., Vanicek, T., Hahn, A., et al. (2017). Association of protein distribution and gene expression revealed by pet and postmortem quantification in the serotonergic system of the human brain. Cerebral Cortex, 27(1):117-130.

[44] Larsen, B., Cui, Z., Adebimpe, A., Pines, A. R., AlexanderBloch, A., Bertolero, M., Calkins, M. E., Gur, R. E., Gur, R. C., Mahadevan, A. S., et al. (2021). A developmental reduction of the excitation: Inhibition ratio in association cortex during adolescence. bioRxiv.

[45] Li, G.-W., Burkhardt, D., Gross, C., and Weissman, J. S. (2014). Quantifying absolute protein synthesis rates 
reveals principles underlying allocation of cellular resources. Cell, 157(3):624-635.

[46] Liu, Y., Beyer, A., and Aebersold, R. (2016). On the dependency of cellular protein levels on mrna abundance. Cell, 165(3):535-550.

[47] Markello, R., Arnatkeviciute, A., Poline, J.-B., Fulcher, B. D., Fornito, A., and Misic, B. (2021). Standardizing workflows in imaging transcriptomics with the abagen toolbox. bioRxiv.

[48] Markello, R. and Misic, B. (2020). Comparing spatiallyconstrained null models for parcellated brain maps. BioRxiv.

[49] Markello, R. D. and Misic, B. (2021). Comparing spatial null models for brain maps. NeuroImage, page 118052.

[50] Matuskey, D., Bhagwagar, Z., Planeta, B., Pittman, B., Gallezot, J.-D., Chen, J., Wanyiri, J., Najafzadeh, S., Ropchan, J., Geha, P., et al. (2014). Reductions in brain 5$\mathrm{ht} 1 \mathrm{~b}$ receptor availability in primarily cocaine-dependent humans. Biological psychiatry, 76(10):816-822.

[51] Mesulam, M.-M. (1998). From sensation to cognition. Brain, 121(6):1013-1052.

[52] Mühleisen, T., Zhao, L., Hilger, D., Burger, B., Forstner, A., Herms, S., Hoffmann, P., Zilles, K., Amunts, K., Cichon, S., and Palomer-Gallagher, N. (2021). Comparison of transcript levels adn neurotransmitter receptor densities in human hippocampal regions. In 27th Annual Meeting of the Organization for Human Brain Mapping.

[53] Mulligan, M. K., Wang, X., Adler, A. L., Mozhui, K., Lu, L., and Williams, R. W. (2012). Complex control of gaba (a) receptor subunit mrna expression: variation, covariation, and genetic regulation. PloS one, 7(4):e34586.

[54] Murrough, J. W., Czermak, C., Henry, S., Nabulsi, N., Gallezot, J.-D., Gueorguieva, R., Planeta-Wilson, B., Krystal, J. H., Neumaier, J. F., Huang, Y., et al. (2011a). The effect of early trauma exposure on serotonin type $1 \mathrm{~b}$ receptor expression revealed by reduced selective radioligand binding. Archives of general psychiatry, 68(9):892900.

[55] Murrough, J. W., Henry, S., Hu, J., Gallezot, J.-D., Planeta-Wilson, B., Neumaier, J. F., and Neumeister, A. (2011b). Reduced ventral striatal/ventral pallidal serotonin $1 \mathrm{~b}$ receptor binding potential in major depressive disorder. Psychopharmacology, 213(2):547-553.

[56] Naganawa, M., Nabulsi, N., Henry, S., Matuskey, D., Lin, S.-F., Slieker, L., Schwarz, A. J., Kant, N., Jesudason, C., Ruley, K., et al. (2021). First-in-human assessment of 11clsn3172176, an $\mathrm{m} 1$ muscarinic acetylcholine receptor pet radiotracer. Journal of Nuclear Medicine, 62(4):553-560.

[57] Neumeister, A., Normandin, M. D., Murrough, J. W., Henry, S., Bailey, C. R., Luckenbaugh, D. A., Tuit, K., Zheng, M.-Q., Galatzer-Levy, I. R., Sinha, R., et al. (2012). Positron emission tomography shows elevated cannabinoid $\mathrm{cb} 1$ receptor binding in men with alcohol dependence. Alcoholism: Clinical and Experimental Research, 36(12):2104-2109.

[58] Nørgaard, M., Beliveau, V., Ganz, M., Svarer, C., Pinborg, L. H., Keller, S. H., Jensen, P. S., Greve, D. N., and Knudsen, G. M. (2021). A high-resolution in vivo atlas of the human brain's benzodiazepine binding site of gabaa receptors. NeuroImage, 232:117878.

[59] Normandin, M. D., Zheng, M.-Q., Lin, K.-S., Mason, N. S., Lin, S.-F., Ropchan, J., Labaree, D., Henry, S., Williams, W. A., Carson, R. E., et al. (2015). Imaging the cannabinoid cb1 receptor in humans with [11c] omar: assess- ment of kinetic analysis methods, test-retest reproducibility, and gender differences. Journal of Cerebral Blood Flow \& Metabolism, 35(8):1313-1322.

[60] Palomero-Gallagher, N. and Zilles, K. (2019). Cortical layers: Cyto-, myelo-, receptor-and synaptic architecture in human cortical areas. Neuroimage, 197:716-741.

[61] Paquola, C., De Wael, R. V., Wagstyl, K., Bethlehem, R. A., Hong, S.-J., Seidlitz, J., Bullmore, E. T., Evans, A. C., Misic, B., Margulies, D. S., et al. (2019). Microstructural and functional gradients are increasingly dissociated in transmodal cortices. PLoS biology, 17(5):e3000284.

[62] Parker, C. A., Rabiner, E. A., Gunn, R. N., Searle, G., Martarello, L., Comley, R. A., Davy, M., Wilson, A. A., Houle, S., Mizrahi, R., et al. (2015). Human kinetic modeling of the 5 ht 6 pet radioligand 11c-gsk215083 and its utility for determining occupancy at both $5 \mathrm{ht} 6$ and $5 \mathrm{ht} 2 \mathrm{a}$ receptors by sb742457 as a potential therapeutic mechanism of action in alzheimer disease. Journal of Nuclear Medicine, 56(12):1901-1909.

[63] Pittenger, C., Adams Jr, T. G., Gallezot, J.-D., Crowley, M. J., Nabulsi, N., Ropchan, J., Gao, H., Kichuk, S. A., Simpson, R., Billingslea, E., et al. (2016). Ocd is associated with an altered association between sensorimotor gating and cortical and subcortical 5-ht1b receptor binding. Journal of affective disorders, 196:87-96.

[64] Preller, K. H., Burt, J. B., Ji, J. L., Schleifer, C. H., Adkinson, B. D., Stämpfli, P., Seifritz, E., Repovs, G., Krystal, J. H., Murray, J. D., et al. (2018). Changes in global and thalamic brain connectivity in lsd-induced altered states of consciousness are attributable to the 5-ht2a receptor. Elife, 7:e35082.

[65] Preller, K. H., Duerler, P., Burt, J. B., Ji, J. L., Adkinson, B., Stämpfli, P., Seifritz, E., Repovš, G., Krystal, J. H., Murray, J. D., et al. (2020). Psilocybin induces time-dependent changes in global functional connectivity. Biological psychiatry, 88(2):197-207.

[66] Radhakrishnan, R., Matuskey, D., Nabulsi, N., Gaiser, E., Gallezot, J.-D., Henry, S., Planeta, B., Lin, S.-f., Ropchan, J., Huang, Y., et al. (2020). In vivo 5-ht6 and 5-ht2a receptor availability in antipsychotic treated schizophrenia patients vs. unmedicated healthy humans measured with [11c] gsk215083 pet. Psychiatry Research: Neuroimaging, 295:111007.

[67] Radhakrishnan, R., Nabulsi, N., Gaiser, E., Gallezot, J.-D., Henry, S., Planeta, B., Lin, S.-f., Ropchan, J., Williams, W., Morris, E., et al. (2018). Age-related change in 5-ht6 receptor availability in healthy male volunteers measured with 11c-gsk215083 pet. Journal of Nuclear Medicine, 59(9):1445-1450.

[68] Ranganathan, M., Cortes-Briones, J., Radhakrishnan, R., Thurnauer, H., Planeta, B., Skosnik, P., Gao, H., Labaree, D., Neumeister, A., Pittman, B., et al. (2016). Reduced brain cannabinoid receptor availability in schizophrenia. Biological psychiatry, 79(12):997-1005.

[69] Rizzo, G., Veronese, M., Heckemann, R. A., Selvaraj, S., Howes, O. D., Hammers, A., Turkheimer, F. E., and Bertoldo, A. (2014). The predictive power of brain mrna mappings for in vivo protein density: a positron emission tomography correlation study. Journal of Cerebral Blood Flow \& Metabolism, 34(5):827-835.

[70] Sanchez-Rangel, E., Gallezot, J.-D., Yeckel, C. W., Lam, W., Belfort-DeAguiar, R., Chen, M.-K., Carson, R. E., Sherwin, R., and Hwang, J. J. (2020). Norepinephrine transporter availability in brown fat is reduced in obesity: a 
human pet study with [11 c] mrb. International Journal of Obesity, 44(4):964-967.

[71] Sandiego, C. M., Gallezot, J.-D., Lim, K., Ropchan, J., Lin, S.-f., Gao, H., Morris, E. D., and Cosgrove, K. P. (2015). Reference region modeling approaches for amphetamine challenge studies with [11c] flb 457 and pet. Journal of Cerebral Blood Flow \& Metabolism, 35(4):623-629.

[72] Sandiego, C. M., Matuskey, D., Lavery, M., McGovern, E., Huang, Y., Nabulsi, N., Ropchan, J., Picciotto, M. R., Morris, E. D., McKee, S. A., et al. (2018). The effect of treatment with guanfacine, an alpha2 adrenergic agonist, on dopaminergic tone in tobacco smokers: An [11 c] flb457 pet study. Neuropsychopharmacology, 43(5):1052-1058.

[73] Saricicek, A., Chen, J., Planeta, B., Ruf, B., Subramanyam, K., Maloney, K., Matuskey, D., Labaree, D., Deserno, L., Neumeister, A., et al. (2015). Test-retest reliability of the novel 5-ht 1b receptor pet radioligand [11 c] p943. European journal of nuclear medicine and molecular imaging, 42(3):468-477.

[74] Savli, M., Bauer, A., Mitterhauser, M., Ding, Y.-S., Hahn, A., Kroll, T., Neumeister, A., Haeusler, D., Ungersboeck, J., Henry, S., et al. (2012). Normative database of the serotonergic system in healthy subjects using multi-tracer pet. Neuroimage, 63(1):447-459.

[75] Scherrer, G., Tryoen-Tóth, P., Filliol, D., Matifas, A., Laustriat, D., Cao, Y. Q., Basbaum, A. I., Dierich, A., Vonesh, J.-L., Gavériaux-Ruff, C., et al. (2006). Knockin mice expressing fluorescent $\delta$-opioid receptors uncover $\mathrm{g}$ proteincoupled receptor dynamics invivo. Proceedings of the National Academy of Sciences, 103(25):9691-9696.

[76] Schwanhäusser, B., Busse, D., Li, N., Dittmar, G., Schuchhardt, J., Wolf, J., Chen, W., and Selbach, M. (2011). Global quantification of mammalian gene expression control. Nature, 473(7347):337-342.

[77] Serdiuk, T., Steudle, A., Mari, S. A., Manioglu, S., Kaback, H. R., Kuhn, A., and Müller, D. J. (2019). Insertion and folding pathways of single membrane proteins guided by translocases and insertases. Science advances, 5(1):eaau6824.

[78] Sharma, K., Schmitt, S., Bergner, C. G., Tyanova, S., Kannaiyan, N., Manrique-Hoyos, N., Kongi, K., Cantuti, L., Hanisch, U.-K., Philips, M.-A., et al. (2015). Cell typeand brain region-resolved mouse brain proteome. Nature neuroscience, 18(12):1819-1831.

[79] Shine, J. M. (2019). Neuromodulatory influences on integration and segregation in the brain. Trends in cognitive sciences, 23(7):572-583.

[80] Shine, J. M., Breakspear, M., Bell, P. T., Martens, K. A. E., Shine, R., Koyejo, O., Sporns, O., and Poldrack, R. A. (2019). Human cognition involves the dynamic integration of neural activity and neuromodulatory systems. Nat Neurosci, 22(2):289-296.

[81] Slifstein, M., Van De Giessen, E., Van Snellenberg, J., Thompson, J. L., Narendran, R., Gil, R., Hackett, E., Girgis, R., Ojeil, N., Moore, H., et al. (2015). Deficits in prefrontal cortical and extrastriatal dopamine release in schizophrenia: a positron emission tomographic functional magnetic resonance imaging study. JAMA psychiatry, 72(4):316-324.

[82] Smart, K., Cox, S. M., Scala, S. G., Tippler, M., Jaworska, N., Boivin, M., Séguin, J. R., Benkelfat, C., and Leyton, M. (2019). Sex differences in [11 c] abp688 binding: a positron emission tomography study of mglu5 receptors. European journal of nuclear medicine and molecular imaging, 46(5):1179-1183.

[83] Smith, C. T., Crawford, J. L., Dang, L. C., Seaman, K. L., San Juan, M. D., Vijay, A., Katz, D. T., Matuskey, D., Cowan, R. L., Morris, E. D., et al. (2019). Partial-volume correction increases estimated dopamine d2-like receptor binding potential and reduces adult age differences. Journal of Cerebral Blood Flow \& Metabolism, 39(5):822-833.

[84] Suárez, L. E., Markello, R. D., Betzel, R. F., and Misic, B. (2020). Linking structure and function in macroscale brain networks. Trends Cogn Sci.

[85] Vázquez-Rodríguez, B., Suárez, L. E., Markello, R. D., Shafiei, G., Paquola, C., Hagmann, P., Van Den Heuvel, M. P., Bernhardt, B. C., Spreng, R. N., and Misic, B. (2019). Gradients of structure-function tethering across neocortex. Proceedings of the National Academy of Sciences, 116(42):21219-21227.

[86] Wang, Z., Gerstein, M., and Snyder, M. (2009). Rna-seq: a revolutionary tool for transcriptomics. Nature reviews genetics, 10(1):57-63.

[87] Yudowski, G. A., Puthenveedu, M. A., and von Zastrow, M. (2006). Distinct modes of regulated receptor insertion to the somatodendritic plasma membrane. Nature neuroscience, 9(5):622-627.

[88] Zakiniaeiz, Y., Hillmer, A. T., Matuskey, D., Nabulsi, N., Ropchan, J., Mazure, C. M., Picciotto, M. R., Huang, Y., McKee, S. A., Morris, E. D., et al. (2019). Sex differences in amphetamine-induced dopamine release in the dorsolateral prefrontal cortex of tobacco smokers. Neuropsychopharmacology, 44(13):2205-2211.

[89] Zhang, Y., Chen, K., Sloan, S. A., Bennett, M. L., Scholze, A. R., O'Keeffe, S., Phatnani, H. P., Guarnieri, P., Caneda, C., Ruderisch, N., et al. (2014). An rna-sequencing transcriptome and splicing database of glia, neurons, and vascular cells of the cerebral cortex. Journal of Neuroscience, 34(36):11929-11947.

[90] Zilles, K., Bacha-Trams, M., Palomero-Gallagher, N., Amunts, K., and Friederici, A. D. (2015). Common molecular basis of the sentence comprehension network revealed by neurotransmitter receptor fingerprints. Cortex, 63:79-89.

[91] Zilles, K. and Palomero-Gallagher, N. (2017). Multiple transmitter receptors in regions and layers of the human cerebral cortex. Frontiers in neuroanatomy, 11:78.

[92] Zilles, K., Schleicher, A., Palomero-Gallagher, N., and Amunts, K. (2002). Quantitative analysis of cyto-and receptor architecture of the human brain. In Brain mapping: the methods, pages 573-602. Elsevier. 

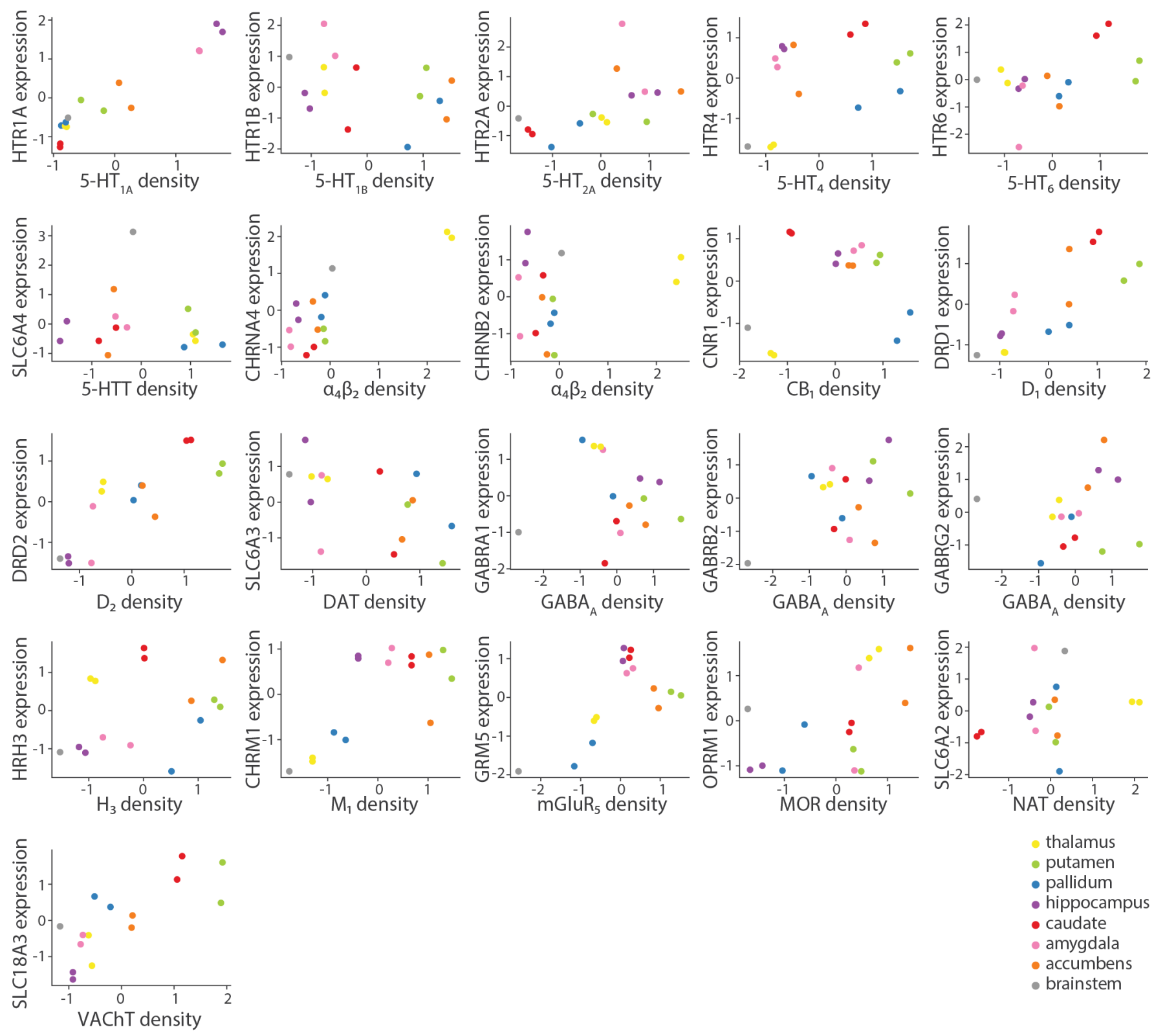

thalamus
- putamen
- pallidum
- hippocampus
- caudate
- amygdala
- accumbens
- brainstem

Figure S1. Correspondence between gene expression and receptor/transporter density in the subcortex | PET receptor/transporter densities and microarray gene expression was parcellated into 15 subcortical regions and correlated. 

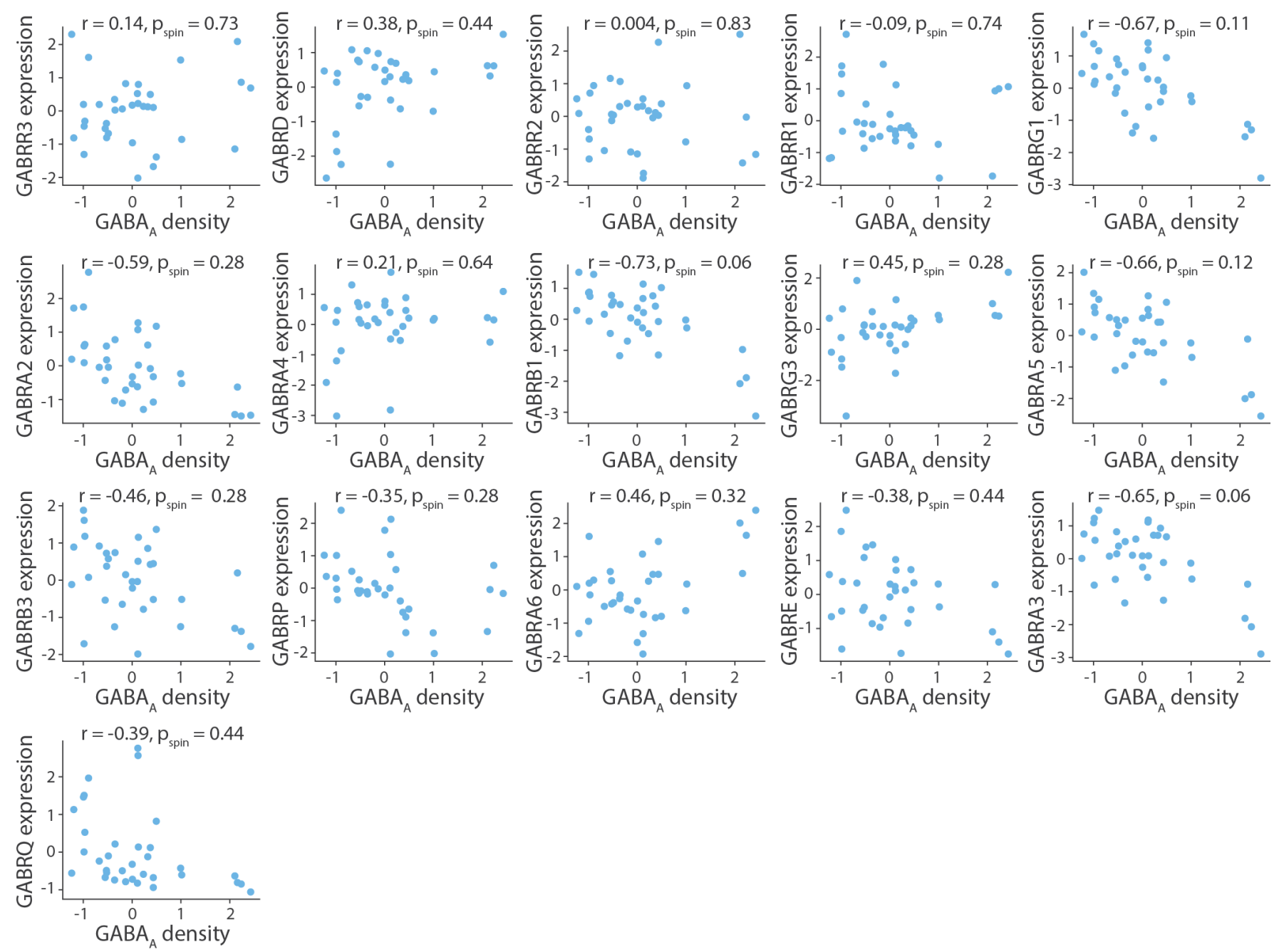

Figure S2. Density-expression association for the remaining sixteen GABAa subunits | Density-expression association for the remaining sixteen GABAa subunits that do not comprise the main channel show that the expression of four subunits are strongly negatively correlated $(r<-0.6)$ with receptor density $\left(\gamma_{1}, \beta_{1}, \alpha_{5}, \alpha_{3}\right)$, although the relationship is not significant after correcting for multiple comparisons [11]. All receptor densities are z-scored. 
bioRxiv preprint doi: https://doi.org/10.1101/2021.11.30.469876; this version posted December 6, 2021. The copyright holder for this preprint (which was not certified by peer review) is the author/funder, who has granted bioRxiv a license to display the preprint in perpetuity. It is made available under aCC-BY 4.0 International license.
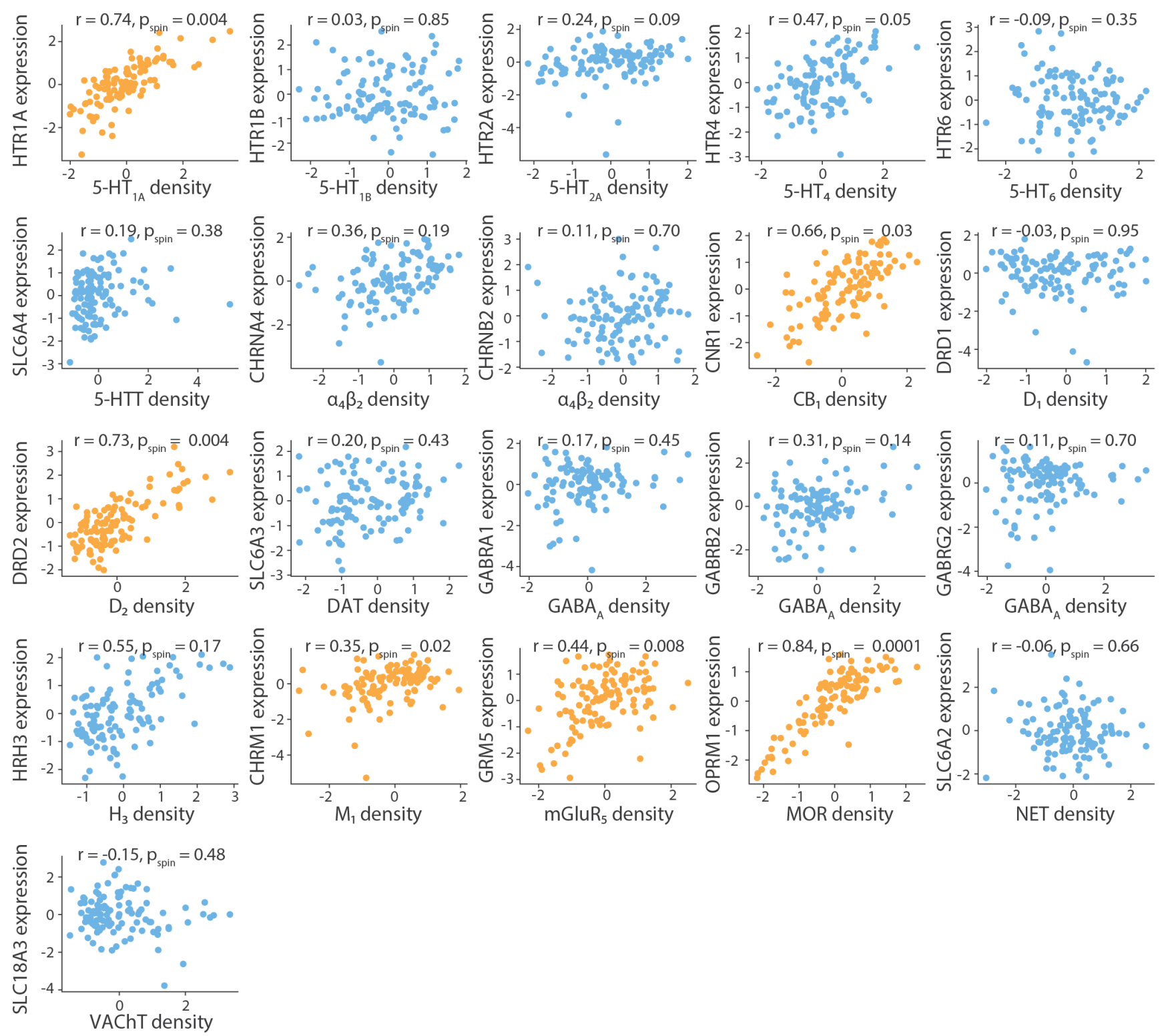

Figure S3. Replication in a 111-node parcellation | PET receptor/transporter densities and gene expression levels were parcellated into a 111-node cortical left hemisphere parcellation. Yellow scatter plots indicate significant density-expression correspondence, against an autocorrelation-preserving null model. All receptor and transporter densities are z-scored. 
bioRxiv preprint doi: https://doi.org/10.1101/2021.11.30.469876; this version posted December $6,2021$. The copyright holder for this preprint (which was not certified by peer review) is the author/funder, who has granted bioRxiv a license to display the preprint in perpetuity. It is made available under aCC-BY 4.0 International license.

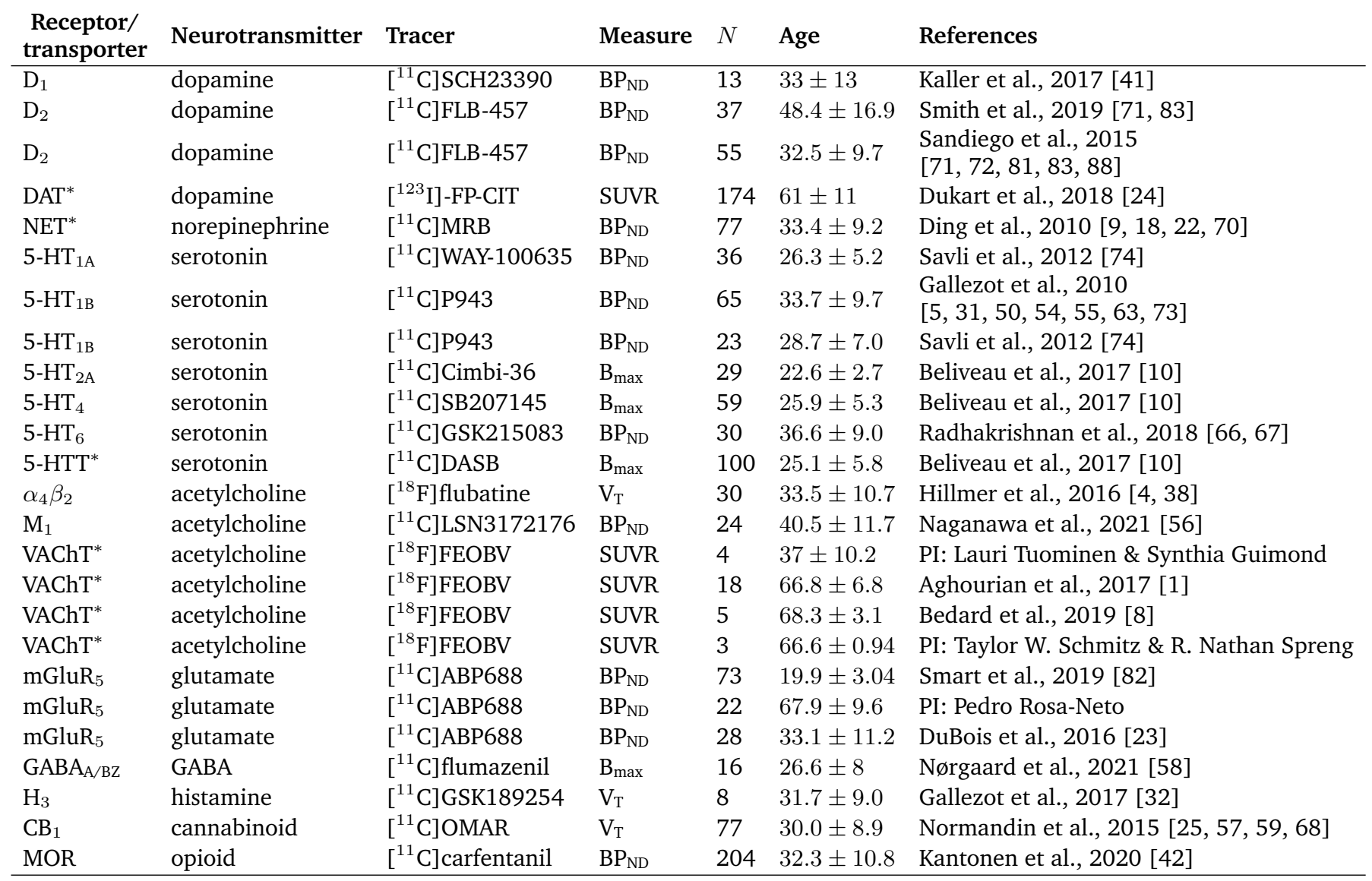

TABLE S1. Neurotransmitter receptors and transporters included in analyses $\mid \mathrm{BP}_{\mathrm{ND}}=$ non-displaceable binding potential; $\mathrm{V}_{\mathrm{T}}=$ tracer distribution volume; $\mathrm{B}_{\max }=$ density $(\mathrm{pmol} / \mathrm{ml})$ converted from binding potential (5-HT) or distributional volume (GABA) using autoradiography-derived densities; SUVR = standard uptake value ratio. Neurotransmitter receptor maps without citations refer to unpublished data. Refer to [35] for more details. Asterisks indicate transporters.

\begin{tabular}{llll} 
Receptor & Neurotransmitter & Excitatory/Inhibitory & Ionotropic/Metabotropic \\
\hline AMPA & glutamate & excitatory & ionotropic \\
NMDA & glutamate & excitatory & ionotropic \\
Kainate & glutamate & excitatory & ionotropic \\
$\mathrm{GABA}_{\mathrm{A}}$ & GABA & inhibitory & ionotropic \\
$\mathrm{GABA}_{\mathrm{A} / \mathrm{BZ}}$ & $\mathrm{GABA}$ & inhibitory & ionotropic \\
$\mathrm{GABA}_{\mathrm{B}}$ & GABA & inhibitory & metabotropic \\
$\mathrm{M}_{1}$ & acetylcholine & excitatory & metabotropic \\
$\mathrm{M}_{2}$ & acetylcholine & inhibitory & metabotropic \\
$\mathrm{M}_{3}$ & acetylcholine & excitatory & metabotropic \\
$\alpha_{4} \beta_{2}$ & acetylcholine & excitatory & ionotropic \\
$\alpha_{1}$ & norepinephrine & excitatory & metabotropic \\
$\alpha_{2}$ & norepinephrine & inhibitory & metabotropic \\
$5-\mathrm{HT}_{1 \mathrm{~A}}$ & serotonin & inhibitory & metabotropic \\
$5-\mathrm{HT}_{2}$ & serotonin & excitatory & metabotropic \\
$\mathrm{D}_{1}$ & dopamine & excitatory & metabotropic \\
\hline
\end{tabular}

TABLE S2. Neurotransmitter receptors included in the autoradiography dataset 